\title{
The Investigation of the English Learning Difficulties of Rural Junior Middle School Students from Students' Subjective Perspective in Jiangxi Province
}

\author{
Zhen Zhou \\ Foreign Languages College, Nanchang Normal University, Nanchang, Jiangxi, 330032 \\ zoye100@sina.com
}

\begin{abstract}
Keywords: Rural junior middle school students; Learning difficulties; Affect; Teachers' teaching
\end{abstract}
\begin{abstract}
The English learning is the important part of junior middle school students' study. However, the rural junior middle school students often encounter a lot of difficulties in learning English, which will not only affect their English learning self-confidence and learning achievement, and also affect the quality of rural English teaching. In order to fully understand the students' English learning difficulties in rural junior middle school, the research studies English learning students' difficulties from students' subjective perspective choosing three rural middle schools in the city of Yichun of Jiangxi province of China as the subjects via questionnaires and interviews, and puts forward the corresponding countermeasures, aiming at providing references for solving the difficulties in the rural junior high school, and further improving English teaching quality in rural areas.
\end{abstract}

\section{Introduction}

The learning difficulty is one of the common problems in students' foreign language teaching and learning, and is also an important issue affecting the quality of foreign language teaching. How to solve the problem of foreign language learning difficulty has attracted the attention of experts and scholars in the areas such as educational psychology and the second language acquisition both at home and abroad. Schwarz argues that students' English learning difficulty mainly is because of different forms of the target language and native language[1]; Ellis indicates the English learning difficulty is mainly due to anxiety, not working hard, weak motivation and bad study habits[2]; Norris - Holt points out that the language learning difficulty is related to motivation, intercultural understanding and social language ability[3]; Westwood states that the English learning difficulty is caused by the improper English teachers teaching method, unsuitable English teaching material arrangement, backward social economy, unharmonious relationship between teachers and students, backward teaching facilities, poor health and so on[4] [5].

Chinese scholars Duan Chengrong and $\mathrm{Ni} \mathrm{Wu}$, Du Ailing, explore the influence and cause of the difficulties of the rural English education, from such three aspects as the teaching environment, the students themselves and society, and think the difficulty comes from the deviation of the awareness of the education administrative department and teachers in English teaching in primary school English education, which shows that the imbalance of education resources, the difficulty of supplement of specializing in the primary school English teachers and serious lack of off-campus English tutoring[6] [7] [8].

Domestic and foreign researchers have explored the manifestation and the cause of the English learning difficulties, and proposed the corresponding countermeasures from different angles. However the object of study is mainly college students, or all rural left-behind children, and few scholars study the English learning difficulty from the perspective of rural junior middle school students' English learning. Thus there is still a lack of understanding to the status quo of rural junior middle school students' English learning difficulties and causing factors. In order to strengthen the understanding of English learning difficulties of the rural junior middle school students, this article discusses the current situation of English learning difficulties of rural junior middle school students, affecting factors and existing problems, and puts forward corresponding countermeasures via the 
combination of qualitative and quantitative empirical research. This article will not only enrich the existing research on English learning difficulties, will also be conducive to solving China's rural junior middle school English learning difficulties, to provide certain theoretical basis for improving the English teaching quality of junior middle school in the countryside.

\section{The Research Methods}

The Subject of Study. This article aims to studying the students' English learning difficulty of the countryside in the junior middle school to carry out empirical research. The subjects of the questionnaire investigation are students from three rural junior middle school of Yichun City, Jiangxi Province, in China, a total of 1183 students, of which 610 male students and 573 female students.

Research Methods and Means. This study combines quantitative and qualitative methods, and gains data through the questionnaire and interview. The questionnaire is adapted from Qin Zhou's questionnaire: "the questionnaire of rural middle school students' learning difficulty" and the researcher conducts a test on the reliability and validity of the questionnaire and the analysis of questionnaire items [9]. 33 items in the questionnaire are retained, and the reliability of the questionnaire is 0.9032 . In the study, 1183 questionnaires are distributed, the effective retrieval questionnaires are 1155, and effective rate is $98 \%$. Besides, ten students are randomly chosen in each school and interviewed in order to understand students' English learning situation much better.

\section{The Results and Analysis}

Students' Affective Factors. Affect is an important aspect of English learning. Affect has an important influence on cognition [10]. The study results about the investigation and analysis of rural junior middle school students' affective factors in English learning shows that only $40 \%$ students are interested in English, and 50\% of the students are not interested, suggesting that most of the students do not develop good learning interest in English. 56\% students think English is hard, 56\% students think English is very difficult, only 5\% of the students think English is easy; $31 \%$ students think that they have fairly high English learning pressure, 14\% think the pressure is very big, which tells that in general, students have a strong fear of English learning. About the English learning goals, $22 \%$ of the students' goal is clear, $46 \%$ have a definite goal, but there are $32 \%$ students whose goal is not clear; About the purpose of learning English, 61\% students are to better lay the foundation for the future study, $32 \%$ students study in order to cope with the exam, $7 \%$ learn for the sake of parents, which shows that students' goal is clear.

In terms of success attribution, $31 \%$ students attribute success to efforts, $29 \%$ owe success to luck, $28 \%$ think the exam paper is easy, and owing the success to the students' own ability is only $12 \%$. Thus, students' success attribution is generally negative. And as for the attribution of failure, 39\% students think that their efforts are not enough, 32\% doubt their ability is not enough, $14 \%$ think their failure is due to luck, and $15 \%$ students think the article is too hard, which suggests that the vast majority of students can find reason from themselves, but it is only a small number who think their efforts are not enough, there are up to $32 \%$ who think the failure is due to capacity, which indicates there universally exist the problems of failure attribution, and there are negative failure attribution. On student's self-confidence, 30\% students have confidence in English learning, students of no confidence account for $26 \%$, only sometimes confident also accounts for $26 \%$, indicating that students generally lack of confidence.

\section{Students' Learning Situation.}

Capacity Evaluation. Capacity evaluation is also is an important part of English learning. Through the investigation and analysis on rural junior middle school students' own capabilities, the result shows that $54 \%$ students fail the English exam, only $16 \%$ students score more than 80 points, and the overall performance is not ideal. About comprehensive English language ability, $11 \%$ think they are very poor, $41 \%$ say fairly bad, and only $8 \%$ think it is just so-so. So it is clear that the students' comprehensive language ability condition needs to be improved. And the students' 
command of the phonetic symbol is not ideal, only $8 \%$ are familiar with the phonetic symbol, very familiar is $40 \%$. In view of this, teachers should pay more attention to the phonetic symbol teaching. Only 5\% students can completely understand the content in English class, those that can mostly understand the content account for 39\%. The students' listening efficiency of teachers' teaching is not high. About English learning atmosphere in the class, only $10 \%$ students think that is very good, $36 \%$ students think that is better, as many as $46 \%$ of students think it is just so-so. Thus the English learning atmosphere needs to be improved in order to enhance students' English learning interest.

Learning Strategies. Correct learning strategy can improve the efficiency of English learning. In this article, the commonly used learning strategy in students' English learning has been investigated and analyzed, and the results show that 53\% students do not communicate in English with teachers and classmates in the English class. This situation is widespread, which is closely related with our students' shyness. In the English class, there are only 7\% whose attention is greatly concentrated, while $76 \%$ sometimes absent-minded, which is largely related to teacher's teaching. As to whether students carefully review what they have learned in class after class timely, only $2 \%$ students can review the "content" on the day of the learning day, $63 \%$ review when they have time, indicating that students' overall level of learning self-consciousness after-school is not high.

Concerning the arrangement of their spare time, $64 \%$ spend a little time in reading English books or doing their homework, only $19 \%$ students read books or do their homework most of the time. When meeting English learning problems, 59\% students choose to ask students, $11 \%$ students choose to consult teachers, and students are more inclined to turn to classmates for help, which suggests that to some degree, the students are not bold enough to ask teachers questions. In the English learning, students' most commonly used methods rank as follows: memorizing words, reading aloud, reciting the text, reviewing the notes; Memorizing words, reading aloud, reciting the text and listening to the tape and reviewing class notes; Memorizing words, reading aloud, reciting the text, listening to the tape and reciting words; Reading aloud; Memorizing words, reciting the text, listening to the tape and reciting notes. The most commonly used method is to recite words, and students focus too much on memorizing isolated words, and ignore the use of language environment; Besides, the learning resources and learning method students use are very traditional too.

Learning Difficulties. Many difficulties hinder the rural junior middle school students' English learning, and this article studies difficulties from the perspective of students. As for English learning difficulties, $81 \%$ of the students have word memory difficulties, $54 \%$ have grammar difficulty, and the difficulty of listening and reading is of similar proportion (35\%). Students memorize words more by relying on rote memorization, and actually it is easy to forget if there is no context to remember words. And students think the most difficult is reading, then is the listening/grammar, oral English/writing, pronunciation/vocabulary.

As is well known, reading takes a great proportion in the exam, students can't rely on rote memorization to master reading skills. Furthermore reading does not only mean understanding, also depends on the speed and language sense. But generally students' reading amount is not enough, therefore, reading is their biggest problem. Secondly, listening and grammar are very difficult, and the reason ca be that students' listening practice is very limited, and teachers use Chinese to teach English, so students do not have a good English environment for a long time. Hence the language exposure is not enough, and the students' listening and grammar level is difficult to improve.

\section{The Suggestions}

Most of the rural junior middle school students are left-behind students, who have a certain characteristics and complexity. And the analysis of the questionnaire and interview of this article indicate that the students have problems existing in such aspects as students' affective factors, and self-assessment and learning strategies. We need society, family, school and students to work together to solve all these problems. 


\section{To Cultivate Students' Positive Affect}

The survey finds that the rural middle school students' interest in English is not strong, and they generally have a strong fear, think the English learning pressure is big, their attribution is negative, and they do not have enough confidence. Therefore, teachers should abandon the boring, jar-and-mug teaching method, and should adopt flexible and varied teaching methods to stimulate students' interest in learning. What's more, teachers and parents should be more concerned about students, praise and encourage them more. The teacher should attach great importance to process evaluation, summative evaluation is complementary, and the teacher should respect students' individual differences, learn to appreciate each student, pay attention to students' each little progress, so that the students can view themselves positively and correctly, and make them have the correct attribution and more confident. Students themselves also should constantly adjust their state of mind, and learn English positively.

\section{To Form Effective Learning Strategies}

Generally, students have many problems such as phonetic symbol problems, weak reading and listening, poor English comprehensive ability and so on. Thus in the teaching process teachers should pay more attention to the phonetic teaching and reading, listening teaching, adopt communicative approach and task-based teaching method, create a harmonious and active English learning atmosphere, and should also give students more English practice, cultivate students' comprehensive language using ability. Teachers should guide students to use more suitable effective learning strategies, also need to conduct strategy training on the student. In this way the students will realize the importance of learning strategy, can use learning strategies effectively, and attach great importance to the use of meta-cognitive strategy and social strategy. With the joint efforts between the teachers and students, we can form effective learning strategies, improve the comprehensive language using ability, and ultimately improve English.

\section{Conclusion}

At present it is common that there are English learning difficulties existing in rural junior middle school students. The difficulties stem from several factors, internal cause and external cause, but all these difficulties can be overcome. The relationship between all learning difficult factors is complex, and only if we have a comprehensive understanding of the cause of the difficulty, and the society, parents, schools, teachers and students should work together, can rural English teaching quality be improved. This article mainly explores the rural junior middle school students' English learning difficulties and countermeasures from students' affective factors and students' ability. The learning difficulty research, however, is a very complex subject, involving medical, psychology, sociology and pedagogy, and some other fields, and it is closely related to the family, society, schools, teachers and students. This study is merely preliminary discussed since it is restricted by the author's research ability, the environment and the research conditions.

\section{References}

[1] Schwarz, R. Learning disabilities and foreign language learning. LD on line: http//www. ldonline. org/ ld. 1997.

[2] Ellis, R. Understanding second language acquisition. Shanghai Foreign language. education press. 1999.

[3] Norris-Holt, Jacqueline. Motivation as a contributing factor in second language acquisition, J. the Internet TESL Journal. 2001, 7(6).

[4] Westwood, P. Learning and learning difficulties. Hong Kong university press. 2002.

[5] Johnson,W.\& Johnson,T. An overview of cooperative learning.in Thousand, J. etal (Eds), 
Creativity and Collaborative Learning.Baltimore:Brookes Press, 1994.

[6] Chengrong Duan, Ge Yang, Ying Wang. The investigation of the rural left-behind children, J. Journal of University, 2005, (6): 25-29.

[7] $\mathrm{Ni} \mathrm{Wu}$. Tens of millions of rural left-behind children's growth and education, J, Science Research. 2006, (2): 15-16.

[8] Du Ailing. Affect the rural English education cause analysis and countermeasures, J. Agricultural Archaeology. 2011, vol. 3, pp. 270-272.

[9] Qin Zhou. The cause of the rural middle school students' English learning difficulties and countermeasures research, D. Chongqing Normal University outstanding master's thesis. 2011.

[10] Jiamei Lu. Emotional teaching psychology. Shanghai: Shanghai education press. 2000, (11). 